\title{
ALTERATIONS OF PULMONARY FUNCTION IN SPINAL CORD INJURED PATIENTS
}

\author{
By A. Ohry, M.D., M. Molho, M.D. and R. Rozin, M.D. \\ Sir Ludwig Guttmann Spinal Cord Injury Centre and the Respiratory Clinical Physiology \\ Laboratory, Ch. Sheba Medical Centre, Tel-Hashomer, Tel-Aviv University, School of \\ Medicine, Israel
}

Abstract. The vital capacity and forced expiratory volume are studied in 23 patients with spinal cord injury.

\section{INTRODUCTION}

PARALYSIS of respiratory musculature in spinal cord injuries depends upon the level of the injury. Thus, with higher level injuries, there is more disturbance in mechanical function. With a neurologic level above cervical three, mechanical assistance is necessary because almost all muscles involved in respiration are paralysed. Evaluation of the patient in these cases, in addition to the clinical examination, requires measurement of arterial blood gases. In the remaining patients, e.g. those capable of spontaneous respiration, the functional evaluation of respiratory reserve is important. Previous studies have been based mainly on the measurement of vital capacity (Gilliat et al., I948; Cameron et al., I955; Gutmann, 1965), gas exchange (Sinha et al., 1973), and work of breathing (Silver, 1963). The information concerning disturbances in flow rates is very sparse. The purpose of the present study was to investigate other parameters in addition to vital capacity i.e. expiratory flow rates and their relationship to vital capacity.

\section{METHODS AND MATERIALS}

Twenty-three spinal cord injured patients ( 22 men and one woman) injured in either accidents or combat were examined. These patients were aged between I 8 and 38 years and were hospitalised in the Sir Ludwig Guttmann Spinal Cord Injury Centre, Tel-Hashomer, Israel, during the early stages of their injuries (two days to three months).

The patients were divided into four groups according to the level of their cord injuries: six cervical (C), five high dorsal (HD) from DI to D6, low dorsal (LD) from $\mathrm{D}_{7}$ to $\mathrm{D}_{12}$, four lumbar (L). Fourteen of the patients had laminectomies-all these patients were war casualties with open injury and the laminectomy was done for debridement and removal of foreign bodies. The surgical intervention was performed prior to admission to the Spinal Cord Injury Centre. Eleven of the 23 patients had complete cord lesion. Fourteen patients had various chest injuries, six patients had laparotomies, and three patients had both chest injuries and laparotomies. The groups with chest and abdominal injuries were all dorsal or lumbar levels (details of clinical data are summarised in Table I). 
TABLE I

Patient's classification

\begin{tabular}{|c|c|c|c|c|c|c|}
\hline No. & Age/Sex & \multicolumn{2}{|c|}{ Level of injury } & Complications or other injuries & Operations & Spasticity \\
\hline I & $3 I / M$ & $\mathrm{C}_{4}$ & incomplete & & Crutchfield traction & + \\
\hline 2 & $2 \mathrm{I} / \mathrm{M}$ & $\mathrm{C}_{5}$ & incomplete & & Crutchfield traction & ++ \\
\hline 3 & $25 / M$ & $\mathrm{C}_{5}$ & incomplete & $\begin{array}{l}\text { Bilateral pneumothorax } \\
\text { Stress ulcer }\end{array}$ & Laminectomy & +++ \\
\hline 4 & $23 / M$ & $\mathrm{C}_{5}, 6$ & complete & & $\begin{array}{l}\text { Crutchfield traction } \\
\text { Open reduction }\end{array}$ & ++ \\
\hline 5 & I $8 / M$ & $\mathrm{C}_{5}, 6$ & incomplete & Pneumonia & $\begin{array}{l}\text { Crutchfield traction } \\
\text { Laminectomy } \\
\text { Tracheostomy }\end{array}$ & + \\
\hline 6 & I9/F & C6, 7 & incomplete & Clavicular fracture & Crutchfield traction & \pm \\
\hline 7 & $28 / M$ & DI & complete & $\begin{array}{l}\text { Haemathorax } \\
\text { Stress ulcer }\end{array}$ & $\begin{array}{l}\text { Pleural drainage } \\
\text { Laminectomy }\end{array}$ & ++ \\
\hline 8 & $23 / M$ & $\mathrm{D}_{2}$ & complete & Multiple wounds & Laminectomy & ++ \\
\hline 9 & $29 / M$ & $\mathrm{D}_{5}, 6$ & complete & $\begin{array}{l}\text { Haemothorax } \\
\text { Rt. 6th rib fracture }\end{array}$ & $\begin{array}{l}\text { Laminectomy } \\
\text { Pleural drainage }\end{array}$ & ++ \\
\hline IO & $25 / M$ & $\mathrm{D}_{5}, 6$ & complete & $\begin{array}{l}\text { Rt. scapular and } 4 \text { th rib } \\
\text { fracture }\end{array}$ & & +++ \\
\hline I I & $22 / M$ & D6, 7 & complete & $\begin{array}{l}\text { Haemopneumothorax } \\
\text { Stress ulcer }\end{array}$ & Pleural drainage & +++ \\
\hline 12 & $29 / M$ & D7 & incomplete & $\begin{array}{l}\text { Pneumothorax } \\
\text { Lt. Ist and } 2 \text { nd fracture }\end{array}$ & & \pm \\
\hline I3 & $\mathrm{I} 9 / \mathrm{M}$ & D8, 9 & incomplete & $\begin{array}{l}\text { Lt. pneumothorax } \\
\text { 9-II th ribs fracture }\end{array}$ & $\begin{array}{l}\text { Pleural drainage } \\
\text { Laminectomy }\end{array}$ & ++ \\
\hline
\end{tabular}




\begin{tabular}{|c|c|c|c|c|c|c|}
\hline No. & Age/Sex & \multicolumn{2}{|c|}{ Level of injury } & Complications or other injuries & Operations & Spasticity \\
\hline I4 & $25 / M$ & D9, I0 & incomplete & $\begin{array}{l}\text { Haemothorax } \\
\text { Stress ulcer }\end{array}$ & $\begin{array}{l}\text { Pleural drainage } \\
\text { Laminectomy }\end{array}$ & ++ \\
\hline 15 & I9/M & DII & complete & $\begin{array}{l}\text { Pneumothorax, bilateral } \\
\text { I2th rib fracture }\end{array}$ & $\begin{array}{l}\text { Laparotomy } \\
\text { Laminectomy }\end{array}$ & 0 \\
\hline I6 & $20 / M$ & Dio, II & complete & Bilateral haemothorax & $\begin{array}{l}\text { Laminectomy } \\
\text { Pleural drainage } \\
\text { Laparotomy } \\
\text { Tracheostomy }\end{array}$ & 0 \\
\hline 17 & $39 / M$ & Di2 & incomplete & $\begin{array}{l}\text { Pulmonary emboly }+ \text { pleural } \\
\text { effusion }\end{array}$ & & ++ \\
\hline I8 & $34 / M$ & Di2 & complete & Severe abdominal damage & $\begin{array}{l}\text { Colostomy } \\
\text { Nephrectomy } \\
\text { Rt. lung lobectomy }\end{array}$ & 0 \\
\hline 19 & $2 \mathrm{I} / \mathrm{M}$ & Di2 & incomplete & & & \\
\hline 20 & $24 / M$ & $\mathrm{D}_{5}, 6$ & incomplete & $\begin{array}{l}\text { Haemopneumothorax } \\
\text { Ribs fracture } \\
\text { Atelectasis }\end{array}$ & $\begin{array}{l}\text { Pleural drainage } \\
\text { Laminectomy } \\
\text { Femoral thrombectomy }\end{array}$ & ++ \\
\hline $2 \mathrm{I}$ & $33 / \mathrm{M}$ & $\mathrm{L}_{3}, 4$ & complete & Bowel tear & $\begin{array}{l}\text { Laparotomy } \\
\text { Laminectomy } \\
\text { Harrington rod }\end{array}$ & 0 \\
\hline 22 & $26 / M$ & $\mathrm{~L}_{4}$ & incomplete & $\begin{array}{l}\text { Ribs fracture } \\
\text { Abdominal wounds }\end{array}$ & $\begin{array}{l}\text { Laminectomy } \\
\text { Nephrectomy }\end{array}$ & 0 \\
\hline 23 & $20 / M$ & $\mathrm{~L}_{4}$ & complete & Bowel tear & $\begin{array}{l}\text { Laparotomy } \\
\text { Laminectomy }\end{array}$ & 0 \\
\hline
\end{tabular}


The following respiratory parameters were measured immediately upon admission and six months later:

I. Forced Vital Capacity (FVC).

2. Forced Expiratory Volume in one second $\left(\mathrm{FEV}_{1}\right)$.

3. Timed Vital Capacity $\left(\mathrm{FEV}_{1} \%=\left(\frac{\mathrm{FEV}_{1}}{\mathrm{FVC}}\right)\right.$.

4. Forced Mid-expiratory Flow $\left(\mathrm{FMF}_{25 \%-75 \%}\right)$.

5. Forced Expiratory Flow $\left(\mathrm{FEF}_{200-1200}\right)$.

6. Peak Expiratory Flow (PEF).

7. Maximal Expiratory Flow $50\left(\mathrm{MEF}_{50}\right)$.

8. Peak Expiratory Flow-Maximal Flow 50 Ratio $\left(\frac{P E F}{M F_{50}}\right)$.

A physician performed all testing using the Vitalograph spirometer manufactured in England. Three determinations were done and the best was chosen for calculation. The forced vital capacity curves were divided into ten equal parts and the flow was measured with a special ruler manufactured by the Vitalograph Co. The flow rates were than plotted against the vital capacity and flow volume curves were obtained for each patient. In these curves PEF and $\mathrm{MEF}_{50}$ were measured (Molho \& Barzilay, in preparation).

Predicted values were:

I. The normogrammes of the European Committee of Coal and Iron (Cara \& Martin, 1964) showing predicted values of vital capacity and $\mathrm{FEV}_{1}$.

2. The normogrammes of Kory et al. (196I) showing predicted values of FEF and FMF. All volumes were corrected to BTPS.

3. The normogrammes of Bass (1974) showing predicted values of PEF and $\mathrm{MEF}_{50}$. All tests were performed in the supine position at the time of admission to the centre and in the sitting position after an interval of six months.

\section{RESULTS}

The average volumes for each group are summarised in Table II and are expressed as a percentage of predicted values. At admission the FVC was found decreased in all cases, the lowest value being 32 per cent in the $C$ group and the highest value being 70 per cent in the $\mathrm{L}$ group. The rate of improvement of this parameter was most noticeable in the L group ( 22 per cent) and diminished in the groups with higher injury levels.

The FEV 1 was also found decreased as in the case of FVC, with the lowest value in the $C$ group ( 37 per cent) and the highest value in the L group (58.3 per cent). The ratio between two values was normal in the $\mathrm{C}$ and $\mathrm{HD}$ groups and decreased in the LD and $\mathrm{L}$ groups with the decrease most noticeable in the $\mathrm{L}$ group ( 57 per cent). A diminution of FMF was noted in all groups. No correlation can be made between this and level of injury. The values of FMF ranged between 44 to 53 per cent. The rate of improvement in this parameter also did not correlate to the level of injury in the second examination. Almost normal value in $\mathrm{HD}$ and LD groups, slightly decreased ( 73 per cent) in group C and decreased in group L (63 per cent) were found. A greater decrease was noted in the FEF than the 


\section{TABLE II}

Average ventilatory parameters for each cord level group (percentage of predicted)

\begin{tabular}{|c|c|c|c|c|}
\hline Groups & Cervical & High dorsal & Low dorsal & Lumbar \\
\hline $\begin{array}{l}\text { FVCI } \\
\text { FVC2 } \\
\text { d }\end{array}$ & $\begin{array}{r}31 \cdot 65 \\
40 \cdot 78 \\
9 \cdot 13\end{array}$ & $\begin{array}{l}43 \cdot 39 \\
54 \cdot 8 I \\
I I \cdot 42\end{array}$ & $\begin{array}{l}47 \cdot 83 \\
66 \cdot 69 \\
18 \cdot 86\end{array}$ & $\begin{array}{l}69 \cdot 91 \\
92 \cdot 23 \\
22 \cdot 32\end{array}$ \\
\hline $\begin{array}{l}\mathrm{FEV}_{1} \mathrm{I} \\
\mathrm{FEV}_{12} \\
\mathrm{~d}\end{array}$ & $\begin{array}{l}37 \cdot 40 \\
5 \mathrm{I} \cdot 16 \\
13 \cdot 76\end{array}$ & $\begin{array}{l}56 \cdot 74 \\
72 \cdot 69 \\
15 \cdot 95\end{array}$ & $\begin{array}{l}44 \cdot 7 \\
73 \cdot 7 \\
29 \cdot 0\end{array}$ & $\begin{array}{l}58 \cdot 33 \\
82 \cdot 79 \\
24 \cdot 46\end{array}$ \\
\hline $\begin{array}{l}\mathrm{FEV}_{1} \% \mathrm{I} \\
\mathrm{FEV}_{1} \% 2 \\
\mathrm{~d}\end{array}$ & $\begin{array}{l}89 \cdot 3 \\
90 \cdot 93 \\
I \cdot 63\end{array}$ & $\begin{array}{r}85 \cdot 2 \\
92 \cdot 6 \\
7 \cdot 4\end{array}$ & $\begin{array}{r}73 \cdot 1 \\
83 \cdot 0 \mathrm{I} \\
9 \cdot 9 \mathrm{I}\end{array}$ & $\begin{array}{r}57 \cdot 0 \\
64 \cdot 0 \\
7 \cdot 0\end{array}$ \\
\hline $\begin{array}{l}\mathrm{FMF}_{\mathrm{I}} \\
\mathrm{fMf}_{2} \\
\mathrm{~d}\end{array}$ & $\begin{array}{l}48 \cdot 0 \\
72 \cdot 94 \\
24 \cdot 94\end{array}$ & $\begin{array}{l}53 \cdot 31 \\
89 \cdot 9 \\
36 \cdot 59\end{array}$ & $\begin{array}{l}48 \cdot 33 \\
84 \cdot 21 \\
35 \cdot 88\end{array}$ & $\begin{array}{l}43 \cdot 84 \\
62 \cdot 65 \\
18 \cdot 81\end{array}$ \\
\hline $\begin{array}{l}\text { FEFI } \\
\text { FEF2 } \\
\text { d }\end{array}$ & $\begin{array}{l}28 \cdot 26 \\
50 \cdot 05 \\
21 \cdot 79\end{array}$ & $\begin{array}{r}47 \cdot 07 \\
55 \cdot 40 \\
8 \cdot 33\end{array}$ & $\begin{array}{l}3 I \cdot 79 \\
66 \cdot 45 \\
34 \cdot 66\end{array}$ & $\begin{array}{l}31 \cdot 67 \\
54 \cdot 23 \\
22 \cdot 56\end{array}$ \\
\hline $\begin{array}{l}\text { PEFI } \\
P_{d} F_{2}\end{array}$ & $\begin{array}{r}50 \\
60 \\
+10\end{array}$ & $\begin{array}{r}58 \\
54 \\
-4\end{array}$ & $\begin{array}{r}48 \\
63 \\
+15\end{array}$ & $\begin{array}{r}43 \\
52 \\
+9\end{array}$ \\
\hline $\begin{array}{l}\mathrm{MEF}_{50} \mathrm{I} \\
\mathrm{MEF}_{50} 2 \\
\mathrm{~d}\end{array}$ & $\begin{array}{r}49 \\
64 \\
+15\end{array}$ & $\begin{array}{r}50 \\
79 \\
+29\end{array}$ & $\begin{array}{r}49 \\
83 \\
+34\end{array}$ & $\begin{array}{r}40 \\
55 \\
+15\end{array}$ \\
\hline $\begin{array}{l}\text { PEF : } \mathrm{MEF}_{50} \mathrm{I} \\
\text { PEF : } \mathrm{MEF}_{50} 2 \\
\mathrm{~d}\end{array}$ & $\begin{array}{r}I \cdot 77 \\
I \cdot 56 \\
-0 \cdot 19\end{array}$ & $\begin{array}{c}I \cdot 95 \\
I \cdot I 04 \\
-0.846\end{array}$ & $\begin{array}{r}I \cdot 64 \\
I \cdot 2 I \\
-0.43\end{array}$ & $\begin{array}{r}\mathrm{I} \cdot 99 \\
\mathrm{I} \cdot 53 \\
-0.46\end{array}$ \\
\hline
\end{tabular}

Remarks: I-at admission.

2 -after six months.

$\mathrm{d}$-rate of improvement.

FMF also with no correlation to the level of injury. The range of values was from 28 per cent in group $\mathrm{C}$ to 47 per cent in group HD. The rate of improvement of this parameter was less than that of the FMF. The PEF was noted to be decreased mainly in group L (43 per cent) with the least decrease in group HD ( 58 per cent). The rate of change after six months was between -4 per cent and $+\mathrm{I} 5$ per cent. The $\mathrm{MEF}_{50}$ showed a much greater decrease in all groups than that of the PEF at the beginning and a much smaller decrease after six months. Therefore PEF : $\mathrm{MEF}_{50}$ was lower in the follow up testing than in the initial trial. $13 / 2-C$ 


\section{DISCUSSION}

The great importance of respiratory problems in the spinal cord injured is well known. This must be kept in mind when the initiation of physiotherapy and exercise commences in the acute stage of the injury (Dail, I965; Alba et al., 1969; Silver, I97I).

The cervical cord injured patient is more exposed to life-threatening situations because of respiratory insufficiency, aspiration, pneumonia etc. (Guttmann \& Frankel, 1966; Silver, 1966; Silver \& Gibbon, 1968). In these cases only the diaphragm and accessory muscles of the neck function. The diaphragm is innervated by the phrenic nerve which remains intact in injuries below $\mathrm{C}_{4}$. The intercostal muscles are innervated by intercostal nerves. Thus the number and strength of their function depends upon the level and completeness of cord injury. If all the intercostal muscles are paralysed, there is no expansion of the thoracic cage during inspiration. This should not delay the immediate commencement of a programme of exercise and physiotherapy. The abdominal muscles are innervated by the six lower thoracic levels and the first lumbar level. The main function of these muscles is forced expiration (Campbell, I958). Therefore a decrease in pulmonary volume, chiefly the vital capacity, can be expected. The maximal dynamic parameter is a function of the carefully coordinated use of all available inspiratory muscles (Rohn et al., 1946). In addition, both the inspiratory and expiratory flow rates (Jordanoglou \& Pride, 1968; Pride, 1971) which are dependent on muscle tension, are reduced. This is noted especially in the first portion of the expirogram (Pride et al., 1967; Mead et al., 1971). Our results support the expected findings in these injuries. Thus in general we show a correlation between the decrease in FVC and $\mathrm{FEV}_{1}$ and the level of injury except for a few patients in the L and LD groups which showed greater decrease than expected. This is attributed to the associated injuries (Table I).

In the $\mathrm{L}$ group the reduction of $\mathrm{FEV}_{1}$ was more noticeable than the reduction of $\mathrm{FVC}$, hence, $\mathrm{FEV}_{1}$ per cent was only 57 per cent and improved to 64 per cent after six months. This decrease in forced expiratory flow rate can be due to direct or secondary dysfunction of abdominal muscles; it can be evidence of obstructive limitations, however this point was not monitored. Three patients in this group had abdominal and back surgery. FMF, FEF, PEF and $M^{2} F_{50}$ were decreased without corrleation to level of spinal cord injury. FEF and PEF had the greatest decrease, for these parameters which depend upon muscle tension are measured in the first portion of forced expiration (Clement et al., I971; Hyatt \& Black, I973). The FMF and the $\mathrm{MEF}_{50}$ are decreased but to a lesser extent. This is explained by the fact that these two parameters are dependent on the elastic recoil of the lung and the diameters of the bronchioles (Hyatt et al., 1958; Fry \& Hyatt, I960; Mead et al., I967; Jordanoglou \& Pride, 1968). The rate of improvement of these four parameters of expiratory flow are: FMF 29 per cent, $M^{2} F_{50} 50$ per cent, PEF 21 per cent and FEF 22 per cent. As a result FEF : $M_{E F}$ decreased in all four groups after six months. A possible explanation for this greater increase in $\mathrm{MEF}_{50}$ is that the second examination of this parameter was performed under conditions of greater pulmonary volume, namely greater bronchiolar diameter and elastic recoil of the lung. In absolute terms the PEF : $M_{E F}$ was normal. The lack of correlation between the disturbance in parameters dealing with mid- 
expiratory flow rate and the level of injury support the thesis that these parameters are dependent upon the mechanical properties of the lung.

The importance of these results is twofold: firstly it serves as a basis of confirmation of clinical impression, and secondly it enables the clinicians to evaluate objectively the demands placed on the patients during therapy situation. These and other parameters are necessary if comprehensive monitoring of efficiency of physical therapy programmes and proper therapy prescription are to take advantage of maximal patient ability.

\section{SUMMARY}

Low values of vital capacity and forced expiratory volume in one second were found in 23 patients with spinal cord injury in a proportion according to the level of injury. After six months of physiotherapy all above ventilatory parameters improved significantly.

\section{RESUME}

Chez 23 malades qui avaient subi un traumatisme de l'épine dorsale, on a trouve une reduction de la capacité vitale et du volume expiratoire maximal seconde proportionnelle au niveau de la lesion de lepine. Après six mois de physiotherapie on a constate une amélioratien significative des parametres ventilatoires étudiés.

\section{ZUSAMMENFASSUNG}

Bei 23 Patienten mit Rückenmarksverletzung wurden verringerte Werte der vitalen Kapazität und forziertes I Sekunde Volumen propotional mit der Höhe der Verletzung gefunden. Nach sechs monatiger Physiotherapie wurde eine erhebliche Besserung der ventilatoren Paremeter erzielt.

\section{REFERENCES}

AlbA, A. et al. (1969). Proceeding of the I7th Veterans on Spinal Cord Conference, Bronx, N.Y., VA hospital.

BAss, H. (I974). Chest, 63, I7I.

Cameron, G. S., Scott, J. W., Jousse, A. T. \& Botterell, E. H. (1955). Ann. Surg. I4I, 54I.

CARA, M. \& MARTIN, L. (1964). Etablissment des normes physiologiques in L'exploration Fonctionelle pulmonaire. Ed. Med. Flammarian, pp. 97-I I2.

Cheshire, D. J. E. (1964). Paraplegia, I, 252.

Clement, J. \& Van-DeWoestijne, K. P. (I97I). F. Physiol. 31, 55.

DaIL, C. W. (1965). Arch. Phys. Med. Rehabil. 46, 655.

Fry, D. L. \& Hyatt, R. E. (I960). Amer. F. Med. 29, 674.

Gilliat, R. W., Guttmann, L. \& Whitteridge, D. (I948). F. Physiol. I071, 67.

Guttmann, L. \& Silver, J. R. (1965). Paraplegia, 3, I.

Guttmann, L. \& Frankel, H. (1966). Int. F. Paraplegia, 4, 63.

Hyatt, R. E., Schilder, D. P. \& Fry, D. L. (1958). F. Appl. Physiol. 13, 33 I.

Hyatt, R. E. \& Black, L. F. (1973). Am. Rev. Resp. Dis. I07, I9I.

JoRdANOGLOU, J. \& PRIDE, N. B. (I968). Thorax, 23, 38.

Jordanoglou, J. \& Pride, N. B. (I968). Thorax, 23, 23.

Kory, R. C., Calahen, R., Boren, H. G. \& Syner, J. C. (I96I). Am. F. Med. 30, 243. 
Levalien, E. C., \& Fowler, W. S. (1955). Amer. Rev. Tuberc. 72, 783.

Mead, J., Turner, J. M., Macklem, P. T. \& Little, J. B. (1967). F. Appl. Physiol. 23, 646. MolHo, M. \& BARZILAI, Z. (in preparation).

Moran-CAMPBell, E. J. (1958). The Respiratory Muscles and Mechanism of Breathing. The Year Book Publishers, Inc., Chicago.

Pride, N. B. (I97I). Brit. F. Dis. Chest, 65, I35.

Rohn, H., Otis, A. B. (1946). Amer. F. Physiol. 146, I6r.

Silver, J. R. (1963). Paraplegia, I, 204.

Silver, J. R. (1968). Paraplegia, 5, 226.

Silver, J. R., Gibbon, N. O. K. (I968). Brit. Med. F. 4, 47.

Silver, J. R. (197I). Ann. R. Coll. Surg. Eng. 48, 7.

Sinha, R. P., DuCKer, T. B. \& Perot, P. L. (I973). ' f $A M A$, 224, I258. 